\title{
Preparing the Instructional Librarian: Representation of ACRL Roles and Strengths in MLS Course Descriptions
}

\section{Sandra J. Valenti and Brady D. Lund}

\begin{abstract}
As the need for librarians to provide instruction on information literacy and other teaching topics increases, masters of library science students, in turn, need to become better prepared to provide to serve in this role. A content analysis of courses offered by American Library Association accredited masters of library science programs seeks to determine whether course titles and descriptions for instruction-based courses map to the Association of College and Research Libraries' Roles and Strengths of Teaching Librarians document.
\end{abstract}

\section{Introduction}

Many researchers have noted a disconnect between the training for instructional librarians offered by Library and Information Science (LIS) programs and the actual duties, roles, and challenges these librarians face. ${ }^{1}$ While instructional librarians have worked at the American Library Association (ALA) national level to create standards/competencies that define the work they do, many argue that LIS programs have continued to teach outdated or irrelevant content. ${ }^{2}$ As such, training for instructional librarians has emerged as one of the most significant topics in the literature of academic librarianship. ${ }^{3}$ Most of the existing literature that explores this disconnect between LIS practice and LIS education has examined the importance of the teaching role, studied job ads and description to describe new instructional needs, or is based on the perspective of practicing instructional librarians. Few studies examine curriculum to identify whether the discrepancy is evident in the course outlines themselves.

The Roles and Strengths of Teaching Librarians document, published in 2017, ${ }^{4}$ indicates the roles that practicing instructional librarians find relevant to their work. By using these roles to inform the codebook for a content analysis of LIS instructional course descriptions, an indication of alignment (or misalignment) between the content in MLIS instructional librarianship courses and the actual roles/duties of practicing instructional librarians may be found. The findings may be relevant to current and aspiring instructional librarians as well as LIS education programs in the design of curriculum and courses.

Sandra J. Valenti is Assistant Professor at School of Library and Information Management, Emporia State University, email: svalenti@emporia.edu; Brady D. Lund is Doctoral Student at School of Library and Information Management, Emporia State University, email: blund2@emporia.edu. @2021 Sandra J. Valenti and Brady D. Lund, Attribution-NonCommercial (https://creativecommons.org/licenses/by-nc/4.0/) CC BY-NC. 


\section{Research Questions}

To determine how current masters-level coursework addresses education and instruction for future professional librarians, researchers used content analysis methods to examine course titles and descriptions published online by ALA accredited programs. We sought to answer these questions:

1. How are the roles and strengths competencies (advocate, coordinator, instructional designer, leader, lifelong learner, teacher, and teaching partner) represented in stated course titles and descriptions?

2. How many courses offered at each institution, required or optional, have a stated basis in instruction?

3. What terms used to describe course outcomes predominate?

4. Of courses including an instructional component, which are required and which are optional?

5. How may these findings inform future course offerings?

\section{Literature Review}

Literature indicating the need for library instruction to introduce patrons to the library and information retrieval and evaluation techniques has existed for well over a century. ${ }^{5}$ This topic gained significant traction beginning in the 1950s, with publications like Griffin and Clarke's Orientation and Ins8truction of the Graduate Student by University Libraries. ${ }^{6}$ However, library instruction did not become a global focus for academic libraries until the 1970s and 1980s, following the work of Zurkowski in the development of information literacy as a concept and the pressing need of the Information Age to combat information overload and avoid disinformation. During the past three decades, information literacy instruction has emerged as one of the major foci within academic librarianship, and concerns associated with this field have grown abundant in the professional and scholarly literature. This literature review presents an overview both of the development and need for information literacy instruction and of training for information literacy instructors while enrolled as students in LIS programs.

\section{Information Literacy}

Although propaganda and disinformation have been recognized since antiquity, the mainstream acceptance and use of social media platforms has made everyone a content author, introducing new concerns for the production of misleading or false information. Additionally, the 2016 presidential elections and influences from external parties who wished to change its course ushered in a new era of fake news, alternative facts, and post-truth information. ${ }^{7}$

In the not-so-distant past, news reporting was relatively well controlled, while not without bias. Before the proliferation of the internet/social media, reliable information sources were more clearly recognized and easily identifiable as well as being fewer in number, making it easier for consumers of information to make quality decisions on the veracity and reliability of the information with which they were presented. Information inputs, though, have increased exponentially in recent years. In 1974, Zurkowski coined the term "information literacy" as he spoke of information overload, which he said might occur "whenever available information exceeds our capacity to evaluate it." ${ }^{\prime 8}$ Zurkowski suggested only about 17 percent of the population was information literate, noting that those who are trained to evaluate information resources can be considered "information literate," while the remaining population, 
while literate in the sense of being able to read and write, lack the capacity to effectively and efficiently evaluate information. ${ }^{9}$

The same might be said of the US population today. The advent and rapid proliferation of social media and the relatively open platform of information dissemination on the internet have changed the landscape of information. This onslaught of information makes it increasingly hard for the general public to determine which information is accurate and relevant, which information is merely biased or misleading, and which information is, at its heart, intentionally false.

Heidi Julien, in 2005, noted, "Information overload, misinformation, and complex information retrieval systems, in addition to people's natural inclination to be satisfied with conveniently accessible information, regardless of its accuracy or reliability, combine to challenge most claims of competence in information skills." ${ }^{10}$ Improved masters-level instruction on the topics of education, the learner, and the learning environment needs more emphasis so that newly minted professional librarians are equipped with the skills they need to provide instruction for this wide realm of instructional need.

\section{Development of Information Literacy Standards}

The American Library Association (ALA) and American College and Research Libraries (ACRL) division has developed and continues to update standards documents that serve to inform the topic of library instruction. Two recent updates have become available with the ACRL Roles and Strengths of Teaching Librarians $(\mathrm{R} \& S)^{11}$ document and its companion, the Framework for Information Literacy for Higher Education (FIL). ${ }^{12}$

\section{Defining Pedagogical Need}

Even in light of the standards and competencies developed by organizations like ACRL, the lack of pedagogical instruction among LIS/MLIS programs has persistently been noted in the literature of academic librarianship for more than a half-century. Throughout the 1970s and 1980s, it was shown that library schools were not consistently providing formal training in bibliographic instruction..$^{13}$ A study conducted in the spring of 1980 among Pennsylvania academic instruction librarians found that only 30 percent of the 112 who responded "saw credit courses [taken during their MLS programs] as their primary means of preparation,"14 while 56 percent cited self-study (conferences, workshops, in-service programs, and other means were also given as primary sources). Citing the need for "user education," Patterson and Howell noted in 1990 that, although it "[e]merged as a major service among those provided by the academic library, its effective delivery to people in that community is still beset by many difficulties and problems. Professional education for this service remains uneven and haphazard, and few instruction librarians have had the necessary courses and practical experience in their formal library education programs to prepare them even minimally for what is encountered on the job." ${ }^{15}$ In 1993, Shonrock and Mulder surveyed practicing instructional librarians, ${ }^{16}$ finding that very few acquired the traits/competencies needed for their current role from library school; this study was replicated by Westbrock and Fabian in 2010, with similar results found. ${ }^{17}$

The need for formal instruction was also reported by Ashmore in 2002, who noted, "Many individuals in higher education (graduate students, new faculty) find themselves in the awkward position of being asked to teach, although they have never had an education 
course in their life." ${ }^{18}$ In 2003, Davies-Hoffman, Alvarez, Costello, and Emerson describe the efforts of a semester-long program designed to provide instruction on pedagogy for librarians in Western New York State. ${ }^{19}$ This program, the Library Instruction Leadership Academy, or LILAC, proved to be an ACRL award winner for innovation in instruction. Goodsett and Koziura report in their 2016 study that, among 581 US librarians, the second greatest gap in LIS education involves a lack of courses on instruction; another was their feeling of being unprepared to work with emerging technologies. ${ }^{20}$

In the past five years alone, nearly a dozen scholarly publications have been published that indicate the persistence of this problem. These include Hensley's 2015 presentation at the ACRL conference about the failures to adequately prepare instructional librarians, ${ }^{21}$ Saunders 2015 study of ALA-accredited programs' instructional librarianship course syllabi, ${ }^{22}$ and Goodsett and Koziura's 2016 survey of LIS programs' graduates. ${ }^{23}$ The common topic or finding among all of these publications is that LIS programs are still not doing nearly enough to prepare students for instructional roles, and many make little effort to align existing instructional librarianship courses with the practices and competencies within the field.

\section{The DIY Instruction Librarian}

An annotated bibliography of articles pertaining to information literacy and library instruction has been published annually by Reference Services Review since $1973 .{ }^{24}$ Of her observations on compiling the 25th anniversary version, Rader notes the increase in "online searching, online system use, and Internet and Web use." ${ }^{25}$ Articles dealing with instruction regarding electronic information flows increased, as well as articles and site pages dealing with "information literacy, resource-based and active learning, and integrating information literacy" into school curricula starting with elementary grades and continuing to higher education. ${ }^{26}$ "Any educator will tell you that teaching is a lot more than encyclopedic knowledge of a topic and yet many individuals in higher education (graduate students, new faculty) find themselves in the awkward position of being asked to teach, although they have never had an education course in their life." ${ }^{27}$ To combat this lack of formal instruction, Ashmore offers several resources a practicing instruction librarian might employ to develop competency on the topic.

A 2012 focus group comprising nine Association of Research Library (ARL) directors/ deans/university librarians, when asked whether library schools were preparing their graduates to assume positions within changing environments today, said results were uneven. ${ }^{28}$ One focus group member noted that one "[c]an't count on the MLS/MLIS program to deliver what is wanted"; another suggested it shouldn't be assumed that "the new librarian will begin work with the requisite knowledge or skills to do the job expected."29

Independent study on the part of librarians informed one school's efforts to approach pedagogy in a more systematic way. As this school's focus group member stated, "As recent library school graduates, we found ourselves underprepared for the challenge. Even though we put a lot of thought and effort into preparing classes and workshops, they did not always succeed. Time and again, we would face a classroom full of students who paid no attention to the session." ${ }^{30}$ The new instructional librarians found themselves ill-equipped to handle such situations and thus were inclined to turn to the published literature and self-reflection to find solutions. While independent study may be useful in some situations, providing some preparation for teaching roles alongside training for general librarianship would likely provide stronger guidance for further independent study and reflection. 


\section{The Evolving Roles of the Instructional Librarian}

While the instructional role of the librarian has traditionally been viewed only as that of the classroom lecturer, the Roles and Strengths document also notes the need for professionals in this group to have roles as advocate, as coordinator, as lifelong learner, and as leader, along with the more traditional roles of teacher, instructional designer, and teaching partner. Considering the opportunities this changing landscape offers, Mathews, Metko, and Tomlin note that the library's scope is changing from more than a place for learners to create, share, curate, and reflect, "Libraries are repositioning themselves as laboratories for exploration, incubators for ideas, and essential collaborators across the teaching, learning, and research enterprises." ${ }^{\prime 31}$ Mathews et al. also note that, while the need for learners to develop competencies in the acquisition, navigation, and evaluation of information is strong, libraries are moving from transactional to more empowering, partnership models. These too are roles where instructional librarians are forced to "do-it-themselves," as LIS instructional courses (if offered at all) continue to focus on outdated interpretations of the instructional librarian roles.

\section{Research Framework}

\section{Framework for Information Literacy for Higher Education}

In June 2012, a task force recommended the then-current Standards document be significantly revised to reflect current thoughts regarding creation and dissemination of knowledge, changing environments in education and learning, moving away from information literacy to fluency, and to incorporate the concept of multiple literacies, such as digital literacy and media literacy. ${ }^{32}$

Six frames represent the document's central concepts:

- Authority is constructed and contextual

- Information creation as a process

- Information has value

- Research as inquiry

- Scholarship as conversation

- Searching as strategic exploration. ${ }^{33}$

The Framework for Information Literacy document ${ }^{34}$ allowed for focus of new attention on the changing information ecosystem. ${ }^{35}$ Moving from competency standards to a framework was intentional, as it uses connected core concepts with flexible options for their use, instead of any rigid enumeration of skills. ${ }^{36}$

\section{Roles and Strengths of Teaching Librarians}

The Standards for Proficiencies for Instruction Librarians and Coordinators was created with the intention of "focusing on broad areas of proficiency rather than a comprehensive list of skills." ${ }^{\prime \prime 7}$ Recognition of the innovative and creative roles within academic institutions suggested the 2007 document should be reviewed and updated. ${ }^{38}$ To present a more holistic perspective of the range of work done by teaching librarians rather than a list of skills needed to do a specific job, the task force identified seven roles intended to guide instruction librarians: advocate, coordinator, instructional designer, leader, lifelong learner, teacher, teaching partner.

The Roles and Strengths of Teaching Librarians document was approved for use by the ALA board of directors in April 2017. ${ }^{39}$ The document intends to continue to serve as a bridge to the Framework for Information Literacy for Higher Education document. ${ }^{40}$ Many academic li- 
brarians have adopted and modified the framework for suitability in their unique library environment, as evidenced in Julien, Gross, and Latham's 2020 book The Information Literacy Framework: Case Studies of Successful Implementation. ${ }^{41}$

As the Framework for Information Literacy for Higher Education and the Roles and Strengths of Teaching Librarians currently inform the actual teaching practices of academic instructional librarians, these documents also inform the framework for this study. As opposed to Saunder's 2015 study, which presents the findings of a generic content analysis of LIS programs' instructional course syllabi, the content analysis presented in the present study is directly informed by the framework and standards, with the explicit aim of examining alignment between these documents and actual

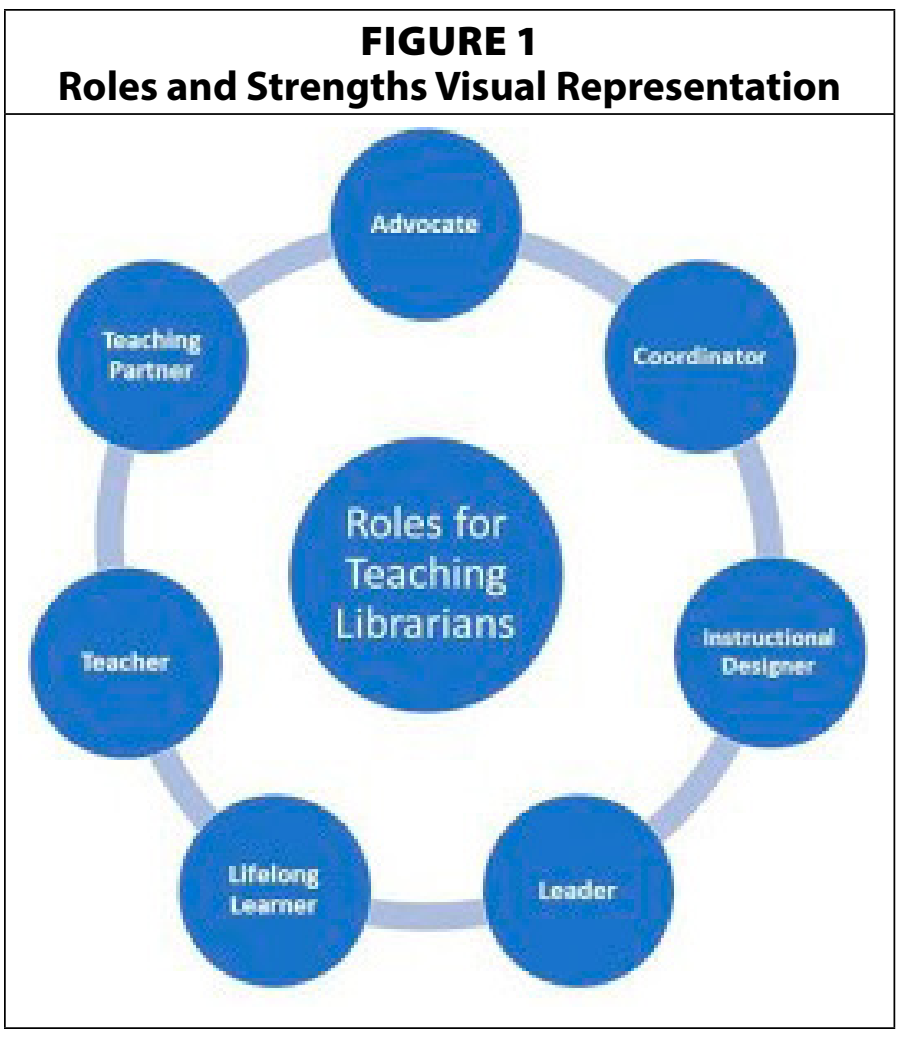
content of LIS instructional courses.

\section{Methods}

This study consisted first of a simple count of all courses at ALA-accredited schools of library and information science that included content in their title or description that aligned with one or more of the ACRL's seven Roles and Strengths, and whether the courses offered were required or optional. This information was gathered from the schools' websites and/or the universities' online course catalogs. The researchers conducted two independent reviews of the websites to make sure no courses fitting the criteria were overlooked. The qualitative aspect of the study involved an examination of course titles and descriptions for specific themes that identify the content taught in these instruction courses.

Content analysis was used as the research methodology for examining the course titles and descriptions, using Krippendorf's criteria:

1. Which data are analyzed?

2. How are the data defined?

3. What is the population from which the data are drawn?

4. What is the context in which the data are being analyzed?

5. What is the scope of the analysis?

6. What is the aim or target of the inferences? ${ }^{42}$

The 61 MLS/MLIS degree-granting programs accredited by the American Library Association's Committee on Accreditation, as listed on the ALA website as of September 2018, ${ }^{43}$ form the basis for this analysis. Course titles and descriptions were collected for each program directly from the universities' websites, either on the program's webpages and/or from the university's academic catalog, which was also browsed via the web. All programs offered this information available online, though, in the instance of the University of Montreal, the con- 
tent had to be translated from French; and, with the University of Puerto Rico, from Spanish; translation software was used to support this process. Courses offered by these programs that included content relevant to library instruction were selected for content analysis. The courses were identified using the course titles and course descriptions to identify language that both researchers deemed to align with teaching skills/instructional librarianship education.

$\mathrm{N}$-vivo qualitative data analysis software was used to assist the researchers with identifying themes and foci in the data. Weber's a priori coding approach ${ }^{44}$ was employed to identify only those data that fit within one of the seven broad roles named in the ACRL's Roles and Strengths of Teaching Librarians (2017): Advocate, Coordinator, Instructional Designer, Leader, Lifelong Learner, Teacher, and Teaching Partner. Within these seven main codes, subcodes/ children were used for any emergent themes in the data fitting within a main theme. These subcodes were identified by both researchers while coding the data within N-vivo, with the names of the subcodes created to represent the coded content as closely as possible. For instance, within the category of instructional designer, subthemes emerged for instructional technology, standards, copyright, and so on. These emergent themes provided insight into the terminology most frequently used in instruction course titles and descriptions. The subcodes/ children were named according to this terminology. Sorting the data using this hierarchical method allowed the researchers to look both generally and specifically at the content of the course descriptions, comparing the descriptions to the ACRL roles while also examining the overall breadth and diversity of the relevant concepts taught in these courses.

Table 1 below provides the definition of each term used as a subcode for the ACRL role of "Instructional Designer." This role was divided into seven subcodes based on themes that emerged from the data: instructional design, instructional technology, library instruction, online learning, standards, assessment, and copyright. The subcodes were determined to adhere to the ACRL role based on the descriptions provided in the Roles and Strengths document.

\begin{tabular}{|l|l|}
\hline \multicolumn{2}{|c|}{ Definitions for Codes and Sub-codes Used in This Study-Instructional Designer } \\
\hline Instructional Designer & $\begin{array}{l}\text { Creates educational experiences through designing instructional materials, } \\
\text { and developing learning outcomes, assessment tools and learning objects } \\
\text { across diverse learning environments. }\end{array}$ \\
\hline Instructional Design & $\begin{array}{l}\text { Creation of learning experiences and materials for the acquisition and } \\
\text { application of knowledge and skills }\end{array}$ \\
\hline Instructional Technology & Evaluation of technology for incorporation into teaching \\
\hline Library Instruction & $\begin{array}{l}\text { Instructional programs designed to teach library users how to locate the } \\
\text { information they need quickly and effectively }\end{array}$ \\
\hline Online Learning & Learning facilitated by internet technology \\
\hline Standards & Set of guidelines pertaining to acceptable quality of a program \\
\hline Assessment & Evaluation of the quality of a program \\
\hline Copyright & Legal right for the publication and reproduction of a work or idea \\
\hline
\end{tabular}

The subcodes for the ACRL Role of "Teacher" are displayed in table 2. The four subcodes of teaching with technology, pedagogy, instructional delivery, and presentation/public speaking emerged as distinct categories of duties assigned to those with the role of teacher. 


\begin{tabular}{|l|l|}
\hline \multicolumn{2}{|c|}{ Definitions for Codes and Sub-codes Used in this Study-Teacher } \\
\hline Teacher & Interacts directly with learners, using learner-centered approach. \\
\hline Teaching with Technology & The integration of information technology in teaching \\
\hline Pedagogy & Method and practice of teaching \\
\hline Instructional Delivery & An instructor's approach to conveying information to students \\
\hline Presentation/Public Speaking & The effective communication of information from instructor to students \\
\hline
\end{tabular}

In table 3 below, the subcodes for each of the remaining five ACRL roles is shown. Each of these roles had only two subcodes emerge.

\begin{tabular}{|c|c|}
\hline \multicolumn{2}{|c|}{ 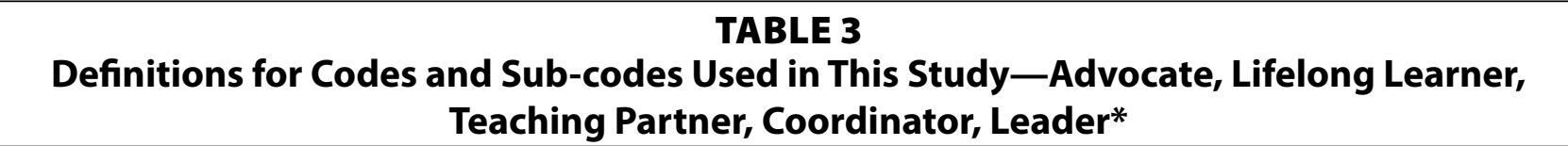 } \\
\hline Advocate & $\begin{array}{l}\text { Persuasion, activism, encouragement, and support pertaining to } \\
\text { information literacy and student learning among the University community. }\end{array}$ \\
\hline Collaboration & Working with someone to produce knowledge or content \\
\hline Outreach & Promoting professional services to administrators, students, and the public \\
\hline Lifelong Learner & $\begin{array}{l}\text { Maintains enthusiasm for teaching through reflective practice and } \\
\text { exploration of new approaches to instruction. }\end{array}$ \\
\hline Professional Development & $\begin{array}{l}\text { Learning to earn or maintain professional credentials and/or stay current } \\
\text { with trends in a profession }\end{array}$ \\
\hline Evidence-Based Practice & Employing research-based evidence to inform instruction \\
\hline Teaching Partner & $\begin{array}{l}\text { Collaborate in different instructional settings with teaching faculty, other } \\
\text { librarians, and other campus colleagues. }\end{array}$ \\
\hline Collaboration & Working with someone to produce knowledge or content \\
\hline Multiple Literacies & $\begin{array}{l}\text { Teaching students to understand a variety of formats of information } \\
\text { presentation }\end{array}$ \\
\hline Coordinator & Leads, develops, and maintains the library instruction program. \\
\hline Assessment & Evaluation of the quality of a program \\
\hline Management & Overseeing the operations of educational programs \\
\hline Leader & Long- and short-term goal development and strategic planning \\
\hline Planning & Making plans for educational programs \\
\hline Guiding & $\begin{array}{l}\text { Providing mentorship, guidance, and being a proactive member of the } \\
\text { learning community }\end{array}$ \\
\hline
\end{tabular}

All parent codes and descriptions are taken from Association of College and Research Libraries (2017). Roles and Strengths of Teaching Librarians. Chicago, IL: American Library Association.

In analyzing the content, the two researchers first read all the data separately. Each researcher then independently coded the data, using the N-vivo software to highlight and assign codes. Finally, the researchers compared and assimilated their codes into one cohesive set. 
Frequencies of each coded theme within the data was calculated and compiled into a single table. This method was employed both for course titles and course descriptions, though each was analyzed in a separate N-vivo "project" and will be displayed in separate tables in the results section.

In this study, a "reference" refers to the inclusion of terms or ideas in a course description that aligns with one of the roles in the Roles and Strengths document, not an explicit mention of that role by name. The researchers used their own discretion in coding for alignment with these roles. For example, it was determined by the researchers that a course on library management does not necessarily equate to the role of Leader or Advocate, as the content of library management courses is generally very broad, whereas leadership and advocacy for instruction is very specific and specialized content that is not covered in these courses. The same is true of topics like assessment, which may be discussed in reference to whole library assessment in management courses, but not in terms of assessment of instruction, which is the context relevant to the Roles and Strengths.

\section{Results}

The initial data collection revealed 107 courses with titles and/or descriptions relevant to the ACRL Roles and Strengths of Teaching Librarians. The second pass identified seven additional courses listed in university catalogs with relevant titles or descriptions that were not listed on the programs' websites. These seven courses were added to the data set. Sixteen of the 114 total courses (from the 58 ALA-accredited institutions with at least one instructional course) were specific to school libraries and were thus separated from the rest of the data set. Of the remaining 98 course descriptions, 25 percent were offered every semester (fall/spring), 70 percent were offered once per year (fall, spring, or summer), and 5 percent were offered once every other year or less often. The number of course descriptions aligning with an ACRL standard at each LIS school, and the number of references to any ACRL standard in these descriptions, is available in the appendix to this article.

The University of Missouri Library Science Program, which shares a school with the Instructional Design and Technology (IDT) department and is located within the College of Education, has the most course descriptions with content relevant to the ACRL's Roles and Strengths, with six. Dominican University's MLIS, also located within the same college as the School of Education, has five courses aligning to the standards by the researchers' mutual assessment. Long Island University (LIU) Post's MLIS, located within the College of Education, Information, and Technology, has four courses aligning with the standards. All other schools have at least one, but not more than three, courses aligning with the ACRL standards.

The University of Denver's Master of Library Science, located within the College of Education, has the greatest occurrence of content that aligns to one of the ACRL Roles and Strengths in its course descriptions, with 17 between two courses. Dominican's MLIS is the only other program to have double-digits in references to an ACRL standard. Missouri, Alberta, Rutgers, LIU Post, and Emporia State (a former Teacher's College) all have nine references to a standard. It appears, both in regard to the number of courses and number of references, that programs affiliated with schools/colleges of education offer stronger alignment with the ACRL Roles and Strengths.

Heidi Julien noted in 2003 that "[c]urrently only one North American library/information science (LIS) school includes instruction as a dedicated core course (the Information 
School, University of Washington), and the last published analysis of instructional courses suggests that only about half of all North American LIS schools offer an elective in instruction." ${ }^{45}$ Fast-forward 13 years, and this situation has not seen much change. Only 3 of 98 courses (at 3 of 58 institutions) reviewed are required; the remaining 95 are optional. Instruction is likely not yet seen as a required educational competency for future librarians within most LIS schools, which may be a reflection of the absence of this competency as a requirement for accreditation of MLS programs by the American Library Association.

Table 4 displays the frequency of each ACRL standard, as well as each of the subcodes, within the course descriptions. The Instructional Designer role had the greatest alignment within course descriptions, with 101 total references. The Teacher role was not far behind, with 79 total references. The remaining standards are not well represented. Coordinator is represented with 40 references, Teaching Partner is referenced 20 times, and Leader, Lifelong Learner, and Advocate roles are each referenced fewer than 10 times. Two roles are disproportionally represented, and three roles are hardly referenced at all. This distribution is also depicted as a pie chart in figure 2.

The two most-referenced roles ("Instructional Designer" and "Teacher") are depicted based on their subcodes in pie charts in figures 3 and 4 below. For the role of Instructional Designer, four subcodes are dominant: Instructional design, Instructional Technology, Standards (like the ACRL Roles and Strengths), and Online Learning Environments. There are three subcodes that were less common: Presentation, Copyright, and Assessment. Assessment, though it is not well-represented as a task of the Instructional Designer, is well-represented under the role of Coordinator. The difference between the two is simply how the assessment is being approached. With

\begin{tabular}{|c|c|}
\hline $\begin{array}{c}\text { TABLE } 4 \\
\text { Frequency of Each } \\
\text { ACRL Standard }(n=260) \\
\text { Sub-codes in the Dat }\end{array}$ & \\
\hline Advocate Total & 6 \\
\hline Outreach & 3 \\
\hline Collaboration & 3 \\
\hline Coordinator Total & 40 \\
\hline Assessment & 29 \\
\hline Management & 11 \\
\hline Instructional Designer Total & 101 \\
\hline Instructional Design & 30 \\
\hline Instructional Technology & 24 \\
\hline Standards & 20 \\
\hline Online Learning & 19 \\
\hline Presentation & 5 \\
\hline Copyright & 3 \\
\hline Assessment & 2 \\
\hline Leader Total & 9 \\
\hline Planning & 7 \\
\hline Guiding & 2 \\
\hline Lifelong Learner Total & 5 \\
\hline Continuing Education & 3 \\
\hline Evidence-Based Practice & 2 \\
\hline Teacher Total & 79 \\
\hline Instructional Delivery & 37 \\
\hline Pedagogy & 34 \\
\hline Teaching with Technology & 6 \\
\hline Public Speaking & 2 \\
\hline Teaching Partner Total & 20 \\
\hline Collaboration & 15 \\
\hline Multiple Literacies & 5 \\
\hline
\end{tabular}
the Coordinator role, assessment is holistic in that the coordinator is determining how well any entire course of study is preparing students and how well instructors are performing; with the Instructional Designer role, assessment is focused on specific assignments and teaching aids that affect instructional delivery on a day-to-day basis.

With the role of Teacher, two subcodes are dominant: Pedagogy and Instructional Delivery. Teaching with Technology is not well-represented; however, it, like with assessment, is closely related with the Instructional Designer subcode of Instructional Technology. The distinction between these two subcodes is in context/approach, with Instructional Technology referring specifically to the technology itself and Teaching with Technology referring to the process of incorporating that technology into instruction. One subcode with few references relative to its 

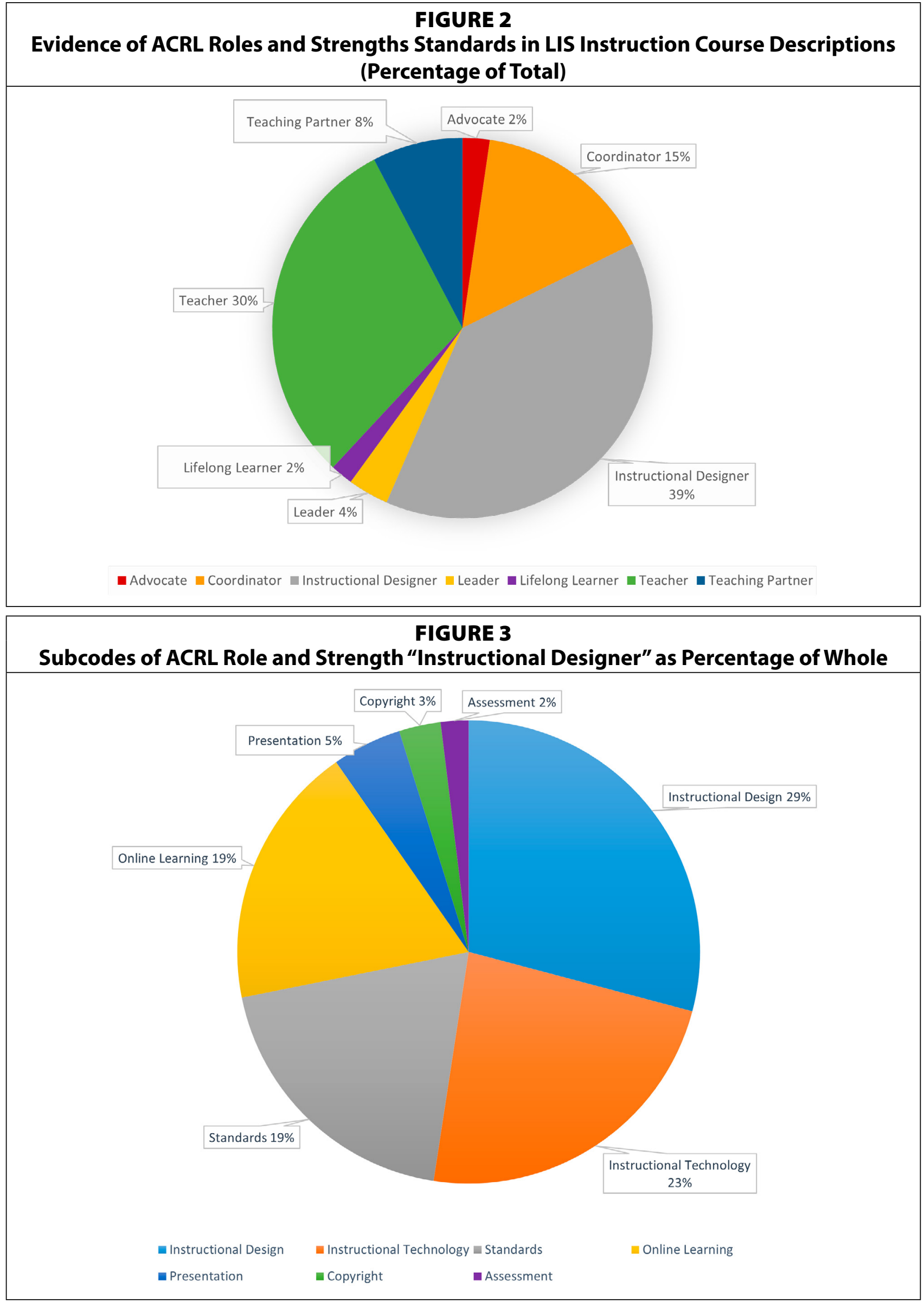


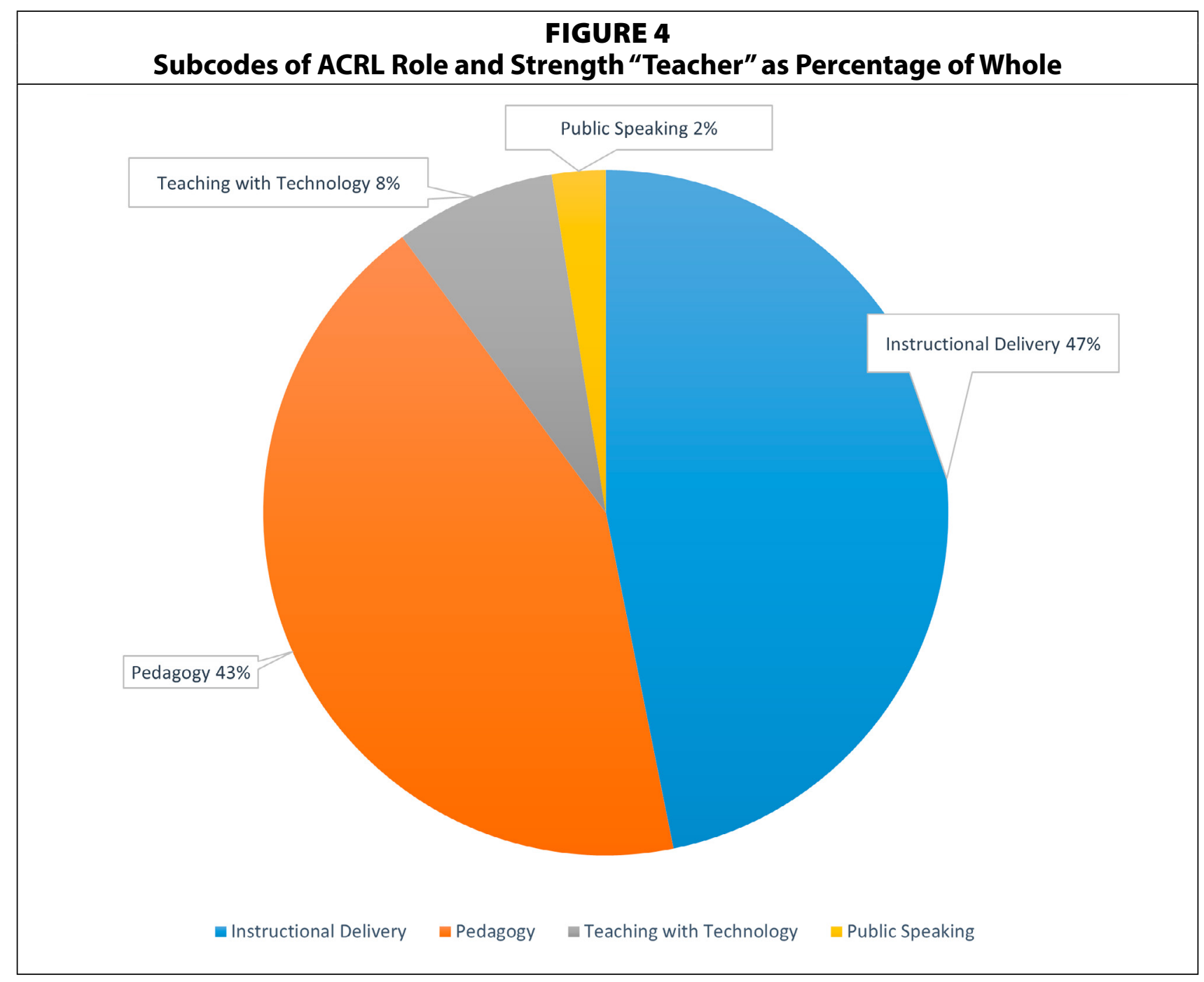

importance in the fulfillment of professional the librarian's role is Public Speaking, with only two references among all 98 courses examined. It is likely that LIS programs believe public speaking, and communication skills in general, are adequately addressed in other areas of the curriculum; however, considering the findings of the Report of the Task Force on the Context of Future Accreditation, conducted by the ALA's Committee on Accreditation, which found that soft skills (particularly communication) were the most desired and most frequently lacked skills among potential library applicants, this is perhaps an area of disconnect. ${ }^{46}$ Considering that instruction is a form of public speaking, one might have anticipated to see this skill area more frequently addressed. Furthermore, public speaking in the context of instruction, like with advocacy and leadership, is significantly different from public speaking in a general setting (like a poster or group presentation).

\section{Discussion}

This study has looked at the ways the Roles and Strengths of Teaching Librarians have been represented in course titles and descriptions. Of the courses reviewed, only three course titles reference the ACRL Roles and Strengths document by name. This factor alone likely indicates that this professional competencies standard is not considered influential within the LIS instructional course curriculum. 
The roles described in the roles and strengths document are not equally represented in course titles or descriptions, nor are the researchers for this study of the opinion that they should be. However, opportunities for courses to provide instruction on how the roles might be fulfilled is abundant, and making reference to the document in course titles and descriptions would bring awareness to its existence of the roles and strengths document.

\section{A Few Exemplars among LIS Programs}

Not all LIS programs did a poor job in aligning with the Roles and Strengths document. Dominican University, for instance, modified its reference and user services course into "LIS 702-Facilitating User Learning and Information Needs," which bridges both information behavior and information literacy/learning science topics. Additionally, the school offers classes (including several that can be substituted for the core technology course in the MLIS program) in educational technology/instructional design, learning theories, and advanced reference and instruction. LIS students interested in instructional librarianship as a career path could take the rotation of courses provided by this school and likely gain competency across most of the ACRL's Roles and Strengths.

Additionally, some LIS programs are actively seeking to improve their instructional librarianship offerings. The University of Arizona, for example, has recently begun offering a graduate certificate in "instruction and teaching for librarians and information professionals." This 12-credit-hour certificate includes courses in information literacy, e-learning for libraries, and instructional design, as well as a 3-credit-hour internship and the development of an e-portfolio to demonstrate student accomplishments. The descriptions of these courses, and the certificate program itself, align them with many of the ACRL's Roles and Strengths.

\section{How Can This Information Inform Future Course Offerings?}

With the lack of reference to instruction-specific advocacy, leadership, and lifelong learner roles, it may be beneficial for LIS programs to integrate this content into instructional course content. While some general content in these areas may be available in other courses, the context of the instructional librarian is unique and likely requires specialized teaching in the types of advocacy, leadership, and lifelong learning relevant to educators (that is to say, informed by the discipline of pedagogy) rather than general librarianship (informed more by management theory and practice).

Generally, LIS programs may benefit from directly using the Roles and Strengths document to inform instructional course content. It is not often that a profession states so clearly what competencies it feels are important for professionals. LIS programs have a roadmap for their courses provided by the ACRL in the form of this Roles and Strengths document and would likely experience better outcomes for students if they allowed it to inform their course content.

\section{Study Limitations}

One limitation of this study was the use of course titles and descriptions for content analysis. While it may be ideal to use a complete syllabus or course materials, it proved extremely difficult to retrieve this information. While some LIS schools provide syllabi freely on their website, others were not made available. Even when provided, available syllabus content varied from the very brief to the very extensive. Thus, course titles and descriptions, which all LIS programs provide, was the most realistic method to advance the analysis. 
Another limitation may be that some courses are improperly titled or described but do contain content relevant to this study and were incorrectly discarded. Similarly, it is possible that some components of a role may be included within a course that otherwise has little to do with instructional librarianship (such as advocacy courses). Often, however, such courses teach concepts broadly, without focusing on the uniqueness of these roles and skills as they pertain to instruction. Advocacy for the public library to the city council is very different from advocacy in the classroom context.

With regard to the content analysis specifically, human bias based on the context of the researchers and developing intercoder agreement is a potential limitation. While the two researchers had different levels of familiarity with the Roles and Strengths document and competencies prior to the research, both can be said to have a level of familiarity that is likely greater than that of the average academic librarian. The researchers also have a similar educational background and affiliation.

\section{Conclusion}

The ALA and ACRL have consistently evaluated, updated, and published documentation that serves to inform the library professional regarding best practices and needed skill sets, including how these might be applied in the instructional environment. The collected data, however, indicates that future library professionals might benefit if the library schools themselves updated their course names and descriptions to better align with those documents. Many of the course descriptions for instructional courses appear to include outdated concepts and fail to prioritize roles highlighted in the ACRL's Roles and Strengths document. Perhaps, by using the Roles and Strengths of Teaching Librarians and the related Framework for Information Literacy for Higher Education, LIS programs may be able to better align their instructional course content with the roles and demands of the instructional position. 


\section{APPENDIX. Number of Courses with Instruction Content and Number of References to an ACRL Role by LIS School}

\begin{tabular}{|c|c|c|}
\hline Name of College/University & $\begin{array}{c}\text { Number of } \\
\text { Instruction Courses }\end{array}$ & $\begin{array}{c}\text { Number of References to any } \\
\text { ACRL Role in Course Descriptions }\end{array}$ \\
\hline Catholic University of America & 2 & 5 \\
\hline Clarion University & 1 & 6 \\
\hline Dalhousie University & 1 & 4 \\
\hline Dominican University & 5 & 10 \\
\hline Drexel University & 1 & 1 \\
\hline East Carolina University & 1 & 2 \\
\hline Emporia State University & 2 & 9 \\
\hline Florida State University & 1 & 4 \\
\hline Hawaii University & 2 & 5 \\
\hline Indiana University & 2 & 6 \\
\hline Kent State University & 1 & 4 \\
\hline Long Island University & 4 & 9 \\
\hline Louisiana State University & 1 & 1 \\
\hline McGill University & 1 & 1 \\
\hline Montreal University & 2 & 3 \\
\hline Pratt Institute & 2 & 7 \\
\hline Queens College & 2 & 2 \\
\hline Rutgers University & 3 & 9 \\
\hline San Jose State University & 3 & 8 \\
\hline Simmons College & 2 & 7 \\
\hline St. Catherine's University & 1 & 8 \\
\hline St. John's University & 1 & 5 \\
\hline State University of New York at Albany & 2 & 3 \\
\hline State University of New York at Buffalo & 2 & 8 \\
\hline Syracuse University & 1 & 3 \\
\hline Texas Women's University & 1 & 2 \\
\hline University of Alabama & 3 & 5 \\
\hline University of Alberta & 1 & 9 \\
\hline University of Arizona & 3 & 3 \\
\hline University of British Columbia & 1 & 5 \\
\hline University of California-Los Angeles & 1 & 2 \\
\hline University of Denver & 2 & 17 \\
\hline University of Illinois & 3 & 5 \\
\hline University of lowa & 1 & 1 \\
\hline University of Maryland & 2 & 4 \\
\hline University of Michigan & 1 & 1 \\
\hline University of Missouri & 6 & 9 \\
\hline
\end{tabular}




\begin{tabular}{|l|c|c|}
\hline Name of College/University & $\begin{array}{c}\text { Number of } \\
\text { Instruction Courses }\end{array}$ & $\begin{array}{c}\text { Number of References to any } \\
\text { ACRL Role in Course Descriptions }\end{array}$ \\
\hline University of North Carolina-Chapel Hill & 1 & 6 \\
\hline University of North Carolina-Greensboro & 3 & 3 \\
\hline University of North Texas & 1 & 2 \\
\hline University of Oklahoma & 1 & 1 \\
\hline University of Ottawa & 1 & 4 \\
\hline University of Pittsburgh & 1 & 3 \\
\hline University of Puerto Rico & 1 & 3 \\
\hline University of Rhode Island & 1 & 2 \\
\hline University of South Carolina & 1 & 6 \\
\hline University of South Florida & 1 & 1 \\
\hline University of Southern California & 1 & 2 \\
\hline University of Southern Mississippi & 1 & 2 \\
\hline University of Tennessee & 1 & 5 \\
\hline University of Texas & 2 & 4 \\
\hline University of Toronto & 1 & 3 \\
\hline University of Washington & 2 & $\mathbf{2 6 0}$ \\
\hline University of Western Ontario & 1 & 4 \\
\hline University of Wisconsin-Madison & 1 & 3 \\
\hline University of Wisconsin-Milwaukee & 2 & 3 \\
\hline Valdosta State University & 1 & 1 \\
\hline Wayne State University & 2 & 3 \\
\hline Totals (58 schools) & & 5 \\
\hline
\end{tabular}

\section{Notes}

1. Jane R. Carter, “Formal Library Science Courses on Library Instruction," Journal of Education for Librarianship 18, no. 4 (1978): 359-61; Robert E. Brundin, "Education for Instructional Librarians: Development and Overview," Journal of Education for Library and Information Science 25, no. 3 (1985): 177-89; Maureen Kilcullen, "Teaching Librarians to Teach: Recommendations on What We Need to Know," Reference Services Review 26, no. 2 (1998): 7-18; Heidi Julien, Melissa Gross, and Don Latham, "Survey of Information Literacy Instructional Practices in US Academic Libraries," College and Research Libraries 79, no. 2 (2018): 179-99.

2. Diana D. Shonrock and Craig Mulder, "Instruction Librarians: Acquiring the Proficiencies Critical to Their Work," College and Research Libraries 54 (1993): 137-49; Theresa Westbrock and Sarah Fabian, "Proficiencies for Instruction Librarians: Is There Still a Disconnect between Professional Education and Professional Responsibilities?" College and Research Libraries 71, no. 6 (2010): 569-90.

3. Heidi Julien, "Information Literacy Instruction in Canadian Academic Libraries: Longitudinal Trends and International Comparisons," College and Research Libraries 61, no. 6 (2000): 510-23; Russell A. Hall, "Beyond the Job Ad: Employers and Library Instruction," College and Research Libraries 74, no. 1 (2013): 24-38; Brady Lund and Ting Wang, "A Comparative Analysis of Instructional Course Themes in LIS and Museum Studies Programs in the USA," Information and Learning Sciences 120, no. 7/8: 426-50.

4. American Library Association (ALA), "Roles and Strengths of Teaching Librarians" (April 28, 2017), www. ala.org/acrl/standards/teachinglibrarians [accessed 7 November 2018].

5. Emma L. Adams et al., "Instruction in the Use of Reference-books and Libraries," Library Journal 23 (1898): $84-86$. 
6. Lloyd W. Griffin and Jack A. Clarke, "Orientation and Instruction of the Graduate Student by University Libraries: A Survey," College and Research Libraries 19, no. 6 (1958): 451-54.

7. Nichole A. Cooke, Fake News and Alternative Facts: Information Literacy in a Post-truth Era, ALA Editions (Chicago, IL: American Library Association, 2018); Lisa Rose-Wiles, "Reflections on Fake News, Librarians, and Undergraduate Research," Reference and User Services Association (2018), https://journals.ala.org/index.php/ rusq/article/view/6606/8827; Laura Saunders, "Information Literacy in Practice: Content and Delivery of Library Instruction Tutorials," Journal of Academic Librarianship 44, no. 2 (2018): 269-78.

8. Paul G. Zurkowski, The Information Service Environment Relationships and Priorities, Related Paper No. 5 (Washington, DC: National Commission on Libraries and Information Science, 1974); Heidi Julien, "Education for Information Literacy Instruction: A Global Perspective," Journal of Education for Library and Information Science 46, no. 3 (2005): 210-16.

9. Zurkowski, Information Service Environment Relationships and Priorities, 6.

10. Zurkowski, Information Service Environment Relationships and Priorities, 6.

11. ALA, "Roles and Strengths of Teaching Librarians" (April 28, 2017), www.ala.org/acrl/standards/teachinglibrarians [accessed 7 November 2018].

12. ALA, "Framework for Information Literacy for Higher Education" (January 11, 2016), www.ala.org/acrl/ standards/ilframework [accessed 12 November 2018].

13. Hopkins, Francis L. "A century of bibliographic instruction: The historical claim to professional and academic legitimacy." College \& Research Libraries 43, no. 3 (1982): 192-98; Russell, Tracy and Randy Hensley. " Education for bibliographic instruction: A recent graduate's view." RQ 29, no. 2 (1989): 189-96.

14. Barbara J. Smith, "Background Characteristics and Education Needs of a Group of Instruction Librarians in Pennsylvania," College and Research Libraries 43, no. 3 (1982): 202.

15. Charles D. Patterson and Donna W. Howell, "Library User Education: Assessing the Attitudes of Those Who Teach," RQ 29, no. 4 (1990): 513-14.

16. Shonrock and Mulder, "Instruction Librarians."

17. Westbrock and Fabian, "Proficiencies for Instruction Librarians."

18. Beth Ashmore, "Up a Creek? Here's a Paddle: An Annotated Bibliography of Recent Resources for New or Occasional Library Instructors," Community and Junior College Libraries 11, no. 1 (2002): 46.

19. Kimberly Davies-Hoffman et al., "Keeping Pace with Information Literacy Instruction for the Real World," Communications in Information Literacy 7, no. 1 (2013): 9-23.

20. Mandi Goodsett and Amanda Koziura, "Are Library Science Programs Preparing New Librarians? Creating a Sustainable and Vibrant Librarian Community," Journal of Library Administration 56 (2016): 697-721.

21. Merinda K. Hensley, "Improving LIS Education in Teaching Librarians to Teach," Proceedings of the ACRL 2015 Conference, March 25-28, 2015, Portland, Oregon, available at https://www.ideals.illinois.edu/bitstream/ handle/2142/73412/ImprovingLISeducation_2015.pdf?sequence=2\&isAllowed=y.

22. Laura Saunders, "Education for Instruction: A Review of LIS Instruction Syllabi," Reference Librarian 56, no. 1 (2015): 1-21.

23. Goodsett and Koziura, "Are Library Science Programs Preparing New Librarians?"

24. Hannelore B. Rader, "Library Instruction and Information Literacy-1999," Reference Services Review 28, no. 4 (2000): 378-400.

25. Rader, "Library Instruction and Information Literacy-1999," 378.

26. Rader, "Library Instruction and Information Literacy-1999," 379.

27. Ashmore, "Up a Creek?" 46.

28. James L. Mullins, "Are MLS Graduates Being Prepared for the Changing and Emerging Roles That Librarians Must Now Assume within Research Libraries?" Journal of Library Administration 51, no. 1 (2012): 124-32.

29. Mullins, "Are MLS Graduates Being Prepared?" 130-31.

30. Martha Bladek and Karen Okamoto, "What's Theory Got to Do with It? Applying Educational Theory and Research to Revamp Freshman Library Workshops," College and Undergraduate Libraries 21, no. 1 (2014): 19-36.

31. Brian Mathews, Stefanie Metko, and Patrick Tomlin, "Empowerment, Experimentation, Engagement: Embracing Partnership Models in Libraries," Educause Review 53, no. 3 (May/June 2018): 52-53.

32. ALA, "Framework for Information Literacy, Appendix 2."

33. ALA, "Framework for Information Literacy."

34. ALA, "Framework for Information Literacy."

35. ALA, "Information Literacy Competency Standards for Higher Education" (January 18, 2000), www.ala. org/Template.cfm?Section=Home\&template=/ContentManagement/ContentDisplay.cfm\&ContentID=33553 [accessed 13 September 2018].

36. ALA, "Information Literacy Competency Standards for Higher Education," 2. 
37. ALA, "Roles and Strengths of Teaching Librarians."

38. ALA, "Roles and Strengths of Teaching Librarians."

39. ALA, "Roles and Strengths of Teaching Librarians."

40. ALA, "Framework for Information Literacy for Higher Education."

41. Heidi Julien, Melissa Gross and Don Latham, The Information Literacy Framework: Case Studies of Successful Implementation (Lanham, MD: Rowman and Littlefield, 2020).

42. Klaus Krippendorf, Content Analysis: An Introduction to Its Methodology (New York, NY: Sage, 1980).

43. ALA, "Directory of ALA-accredited and Candidate Programs in Library and Information Studies" (September 19, 2018), http://web.archive.org/web/20180919074038/http://www.ala.org/educationcareers/accreditedprograms/directory.

44. Robert P. Weber, Basic Content Analysis (New York, NY: Sage, 1990).

45. Julien, "Education for Information Literacy Instruction," 211.

46. ALA Committee on Accreditation, "Report on the Context of Future Accreditation" (March 30, 2017), www.ala.org/aboutala/sites/ala.org.aboutala/files/content/governance/ebd5_9_TFonFutureContextofAccred.pdf [accessed 18 October 2018]. 